\title{
Determination of the chemical compositions of Viscum album ssp. album and soft core hosts
}

\author{
Tamer Üstüner $^{\circledast 1 *}$ and Sema Düzenli ${ }^{\odot 2}$ \\ ${ }^{1}$ Department of Plant Protection, Faculty of Agriculture, University of Kahramanmaras Sutcu Imam, \\ Avsar Campus, Kahramanmaras-Türkiye \\ ${ }^{2}$ Department of Biology, Faculty of science literature, University of Cukurova, Adana-Türkiye \\ (Received July 26, 2017; Revised October 31, 2017; Accepted November 01, 2017)
}

\begin{abstract}
In this study, leaf proportional water content, chlorophyll a and b, total chlorophyll, carotenoid, proline, total amino acid, ascorbic acid, glucose, fructose and sulphydryl group (SH) were determined in both Viscum album ssp. album and its hosts. Physiological alterations in soft-core fruits such as Ankara pear, Braeburn apple and hawtorn when infected with Viscum album ssp. album were investigated. While proportional water content of $V$. $a$. ssp. album was found higher than all fruit trees with or without $V$. album (control), its chlorophyll a content was lower than only control and two hosts (Braeburn apple and Ankara pear). Chlorophyll b content, on the other hand, was similar in all experimental groups for Ankara pear and hawthron whereas, in Braeburn apple, it was significantly higher in control. As for the total chlorophyll and carotenoid contents of V.a. ssp. album, in Breaburn and Ankara pear, they were found less than the controls and hosts whilst in hawthorn, the values were variable. Although proline content of $V$. $a$. ssp. album was higher compared to their controls and hosts, total amino acid, reduced and total ascorbic acid, glucose, fructose and sulphydryl acid in V. a. ssp. album were determined to be lower than all uninfected fruits (control).
\end{abstract}

Keywords: V. album sp album; leaf proportional water; chlorophyll a-b; total chlorophyll; carotenoid.

(C) 2017 ACG Publications. All rights reserved.

\section{Introduction}

The semi parasitic plant $V$. a. ssp. album causes significant loss of yield and quality in fruit production in many countries such as Turkey. Viscum genus of Loranthaceae family in Santalalaes order includes three sub species living as semi parasite on host plants. The sub species, V. album L. ssp. album, V. album L. ssp. abietis (Wiesb.) Abromeit and V. album L. ssp. austriacum (Wiesb.) Vollmann, belonging to Viscum album (mistletoe ), were reported by Miller [1].

$V$. album is a mostly globose perennial evergreen shrub with persistent haustoria in the host. This semi parasite is able to conduct the photosynthesis since it contains chlorophyll $\mathrm{a}$ and $\mathrm{b}$ in its leaves. It takes water and nutrients from the host and produces its own metabolites whenever it has access to light and carbon dioxide. Viscum species using xylem water and dissolved organic substances from their hosts weakens and eventually kills them. $V$. album L. subsp. album, white berry mistletoe (Loranthaceae), is one of the most important biological stress sources for host plants [2-11]. This semi parasite plant feeds on water and nutrients obtained from its host via its haustorium [12].

Subspecies of Viscum album in Turkey are often semi parasite plants living on various fruit trees such as wild pear, hawthorn, pear, quince, apple and apricot. V. a. ssp. album was reported to be

\footnotetext{
* Corresponding author:E-mail: TamerUstuner@ksu.edu.tr; Phone: 90(344) 3002060, Fax: 90(344) 3002002
} 
the most commonly observed on such as fruit trees; Ankara pear, Breaburn apple, almond, apricot, whitehorn, hawthorn, plum and on such as park trees; populus and salix in Nigde,Turkey. The severity of the disease caused by $V$. album ssp. album was determined as the highest on Almond (Amygdalus spp.) 48.54\%, Apricot (Prunus armenica L.) $34.98 \%$ and Pear (Pyrus communis L.) $28.64 \%$. [13-15]. Glucose, fructose and sucrose contents of mistletoe on populus have been shown to be higher in spring than autumn. Xylem of populus contained highest carbohydrate concentrations in spring, and much lower concentrations in the autumn and summer [16]. Moreover, Ziegler et al. [17] measured faster rates of stem flow and transpiration in the mistletoe compared with its woody hosts. The study of the host and mistletoe ecophysiology of Tapinanthus bangwensis on the two hosts, Citrus sinensis and Irvingia gabonensis shows that mistletoe thrives on its hosts on the strength of the available water, mineral nutrients, sugars (photosynthates) and the effective leaf chlorophyll content [18]. According to a study carried out with Dendrophthoe falcata on mango, chlorophyll pigments showed a decrease possibly the reduction in availability of water and minerals. The total protein, phenols, flavonoids also showed a defense related response in the plant but, the chlorophyll content showed a decrease in the infected plant [19].

The aim of this study is to determine the leaf proportional water content, chlorophyll a-b, total chlorophyll, carotenoid, proline, total amino acid, ascorbic acid, glucose, fructose and sulphydryl group (SH) of $V$. a. ssp. album on Ankara pear, Breaburn apple and hawtorn grown in Nigde, Turkey.

\section{Materials and Methods}

Plant materials used in the study were collected from Nigde province of Turkey. These are the leaf of Braeburn apple, Ankara pear, hawthorn and $V$. a. ssp. album between the years of 2014 and 2015.

Based on the meteorological data of Nigde, annual mean temperature was $18.22{ }^{\circ} \mathrm{C}$, relative humidity $47.99 \mathrm{~g} / \mathrm{m}^{3}$, sunning duration 7.14 hours/day, mean wind speed $2.64 \mathrm{~m} / \mathrm{s}$, mean precipitation $0.866 \mathrm{~mm}$ and surface soil temperature $4.44{ }^{\circ} \mathrm{C}$ in these years. The soil of the study area was arid, sandy, slightly alkaline and total salt was low. The $\mathrm{pH}$ of the soil was 7.4, the lime ratio was 7.2, phosphorous content was $3.1 \mathrm{mg} / \mathrm{kg}$, the amount of the organic matter was $0.32 \%$ and the potassium content was $48 \mathrm{mg} / \mathrm{kg}$.

Proportional water content, chlorophyll and carotenoid were calculated as described by Sairam et al. [20] and Arnon [21]. In addition, other parameters were estimated by using the method defined by Lichtenthaler and Wellburn [22]. Analysis of SH-group was made by using 5-5 dithiobis (2nitrobenzoik acid) (DTNB) solution at the 5\% meta- phosphoric acid extraction. Total and reduced ascorbic acid, amino acid and proline were analyzed as previously reported [23-25].

\subsection{Statistical analysis}

In order to determine whether there is a statistically significant difference among the obtained results for each parameter of $V$. a. ssp. album and its hosts, variance analyses were carried out using SPSS 20 software package. Differences between means were tested by Duncan test and ANOVA. The values with a $\mathrm{p}$ value lower than $0.05(\mathrm{p} \leq 0.05)$ were considered significantly different.

\section{Results and discussion}

\subsection{Leaf proportional water content}

In three fruits (Breaburn apple, Ankara pear and hawthorn), leaf proportional water content of $V$. a. ssp. album was determined to be statistically different from control and host plants. Leaf proportional water content of $V$. a. ssp. album was about 3-4 times higher than the control and the host (Table 1). 
Table 1. Proportional water content (\%) of control, hosts and V.a. ssp. album

\begin{tabular}{|c|c|c|c|c|}
\hline \multirow[b]{2}{*}{ Fruit trees } & \multicolumn{4}{|c|}{ Proportional water content (\%) } \\
\hline & Control & Host & V.a. ssp. album & $F$ and $P$ \\
\hline Breaburn apple & $\begin{array}{l}24.761 \pm 2.55 \\
b\end{array}$ & $\begin{array}{l}21.948 \pm 0.849 \\
b\end{array}$ & $\begin{array}{l}86.499 \pm 9.019 \\
\mathrm{a}\end{array}$ & $\begin{array}{l}\mathrm{F}_{2,9}=\text { Infinity } \\
\mathrm{P}<0.0001\end{array}$ \\
\hline Ankara pear & $\begin{array}{l}28.921 \pm 6.16 \\
b\end{array}$ & $\begin{array}{l}25.879 \pm 0.923 \\
\mathrm{~b}\end{array}$ & $\begin{array}{l}67.48 \pm 6.6502 \\
a\end{array}$ & $\begin{array}{l}\mathrm{F}_{2,9}=\text { Infinity } \\
\mathrm{P}<0.0001\end{array}$ \\
\hline Hawthorn & $\begin{array}{l}16.66 \pm 5.03 \\
b\end{array}$ & $\begin{array}{l}14.217 \pm 1.744 \\
b\end{array}$ & $\begin{array}{l}89.266 \pm 5.141 \\
\mathrm{a}\end{array}$ & $\begin{array}{l}\mathrm{F}_{2,9}=803.18 \\
\mathrm{P}<0.0001\end{array}$ \\
\hline
\end{tabular}

One-way analysis of variance (ANOVA) and DUNCAN tests were applied to the data and the differences between the means were calculated at the significance level of $\mathrm{P}<0.05$.

\subsection{Chlorophyll $a-b$}

Chlorophyll a content of $V$. a. ssp. album was found to be lower than control and hosts for Breaburn apple and Ankara pear. However, Chlorophyll a content of $V$. a. ssp. album was found to be similar to the host for hawthorn (Table 2). On the other hand, Chlorophyll b content of $V$. $a$. ssp. album was lower than control and similar to the host for Breaburn apple while it was similar to the control and host for Ankara pear and hawthorn.

Table 2. Chlorophyll a-b contents (mg/g) of control, hosts and V.a. ssp. album

\begin{tabular}{|c|c|c|c|c|c|c|c|c|}
\hline \multirow[b]{2}{*}{ Fruit trees } & \multicolumn{4}{|c|}{ Chlorophyll a content $(\mathrm{mg} / \mathrm{g})$} & \multicolumn{4}{|c|}{ Chlorophyll b content (mg/g) } \\
\hline & Control & Host & $\begin{array}{c}\text { V.a. ssp. } \\
\text { album }\end{array}$ & $F$ and $P$ & Control & Host & $\begin{array}{c}\text { V. a .ssp. } \\
\text { album }\end{array}$ & $F$ and $P$ \\
\hline Breaburn apple & $\begin{array}{c}15.5 \pm 1.0 \\
\mathrm{a}\end{array}$ & $\begin{array}{c}13.8 \pm 0.8 \\
\mathrm{a}\end{array}$ & $\begin{array}{c}3.7 \pm 0.4 \\
\mathrm{~b}\end{array}$ & $\begin{array}{c}F_{2,6}=65.06 \\
P<0.0001\end{array}$ & $\begin{array}{c}4.3 \pm 0.5 \\
\mathrm{a}\end{array}$ & $\begin{array}{c}1.5 \pm 0.3 \\
\mathrm{~b}\end{array}$ & $\begin{array}{c}1.0 \pm 0.18 \\
\mathrm{~b}\end{array}$ & $\begin{array}{c}\mathrm{F}_{2,6}=25.38 \\
\mathrm{P}<0.001\end{array}$ \\
\hline Ankara pear & $\begin{array}{c}23.5 \pm 0.8 \\
\mathrm{a}\end{array}$ & $\begin{array}{c}14.3 \pm 2.4 \\
\mathrm{~b}\end{array}$ & $\begin{array}{c}5.3 \pm 0.8 \\
\mathrm{c}\end{array}$ & $\begin{array}{c}\mathrm{F}_{2,6}=32.84 \\
\mathrm{P}<0.001\end{array}$ & $\begin{array}{c}0.03 \pm 0.07 \\
\mathrm{a}\end{array}$ & $\begin{array}{c}1.7 \pm 0.4 \\
\mathrm{a}\end{array}$ & $\begin{array}{c}0.3 \pm 0.1 \\
\mathrm{a}\end{array}$ & $\begin{array}{l}F_{2,6}=3.10 \\
P=0.1192\end{array}$ \\
\hline Hawthorn & $\begin{array}{c}22.1 \pm 2.3 \\
\mathrm{a}\end{array}$ & $\begin{array}{c}9.2 \pm 1.6 \\
\mathrm{~b}\end{array}$ & $\begin{array}{c}10.3 \pm 0.3 \\
\mathrm{~b}\end{array}$ & $\begin{array}{c}\mathrm{F}_{2,6}=18.30 \\
\mathrm{P}<0.01\end{array}$ & $\begin{array}{c}1.9 \pm 0.2 \\
\mathrm{a}\end{array}$ & $\begin{array}{c}2.8 \pm 0.5 \\
\mathrm{a}\end{array}$ & $\begin{array}{c}3.0 \pm 0.2 \\
\mathrm{a}\end{array}$ & $\begin{array}{l}\mathrm{F}_{2,6}=2.39 \\
\mathrm{P}=0.1722\end{array}$ \\
\hline
\end{tabular}

One-way analysis of variance (ANOVA) and DUNCAN tests were applied to the data and the differences between the means were calculated at the significance level of $\mathrm{P}<0.05$.

\subsection{Total chlorophyll and caroteneoid content}

Although the total chlorophyll and carotenoid contents of $V$. a. ssp. album were found less than control and host for Breaburn and Ankara pear, the total chlorophyll of $V$. a. ssp. album was resembling the host for hawthorn. The carotenoid content of $V$. a. ssp. album was higher in host for hawthorn (Table 3). 
Table 3. Total Chlorophyll and carotenoid contents of control, hosts and V. a. ssp. album

\begin{tabular}{|c|c|c|c|c|c|c|c|c|}
\hline \multirow[b]{2}{*}{ Fruit trees } & \multicolumn{4}{|c|}{ Total Chlorophyll content (mg/g) } & \multicolumn{4}{|c|}{ Carotenoid content (mg/g) } \\
\hline & Control & Host & $\begin{array}{l}\text { V.a. ssp. } \\
\text { album }\end{array}$ & $F$ and $P$ & $\begin{array}{c}\text { Contro } \\
1\end{array}$ & Host & $\begin{array}{l}\text { V.a. ssp. } \\
\text { album }\end{array}$ & $F$ and $P$ \\
\hline Breaburn apple & $\begin{array}{c}19.8 \pm 1.3 \\
\mathrm{a}\end{array}$ & $\begin{array}{c}15.3 \pm 0.6 \\
b\end{array}$ & $\begin{array}{c}4.8 \pm 0.5 \\
c\end{array}$ & $\begin{array}{l}\mathrm{F}_{2,6}=68.29 \\
\mathrm{P}<0.0001\end{array}$ & $\begin{array}{c}6.1 \pm 0.4 \\
\mathrm{a}\end{array}$ & $\begin{array}{c}3.0 \pm 0.1 \\
b\end{array}$ & $\begin{array}{c}1.5 \pm 0.1 \\
\mathrm{c}\end{array}$ & $\begin{array}{c}\mathrm{F}_{2,6}=73.82 \\
\mathrm{P}<0.0001\end{array}$ \\
\hline Ankara pear & $\begin{array}{c}23.4 \pm 1.4 \\
\mathrm{a}\end{array}$ & $\begin{array}{c}16.0 \pm 2.5 \\
b\end{array}$ & $\begin{array}{c}5.7 \pm 0.8 \\
\mathrm{c}\end{array}$ & $\begin{array}{c}\mathrm{F}_{2,6}=24.48 \\
\mathrm{P}<0.01\end{array}$ & $\begin{array}{c}5.2 \pm 0.2 \\
\mathrm{a}\end{array}$ & $\begin{array}{c}3.1 \pm 0.4 \\
\mathrm{~b}\end{array}$ & $\begin{array}{c}1.1 \pm 0.2 \\
\mathrm{c}\end{array}$ & $\begin{array}{c}\mathrm{F}_{2,6}=37.98 \\
\mathrm{P}<0.001\end{array}$ \\
\hline Hawthorn & $\begin{array}{c}24.1 \pm 2.2 \\
\mathrm{a}\end{array}$ & $\begin{array}{c}12.0 \pm 2.1 \\
b\end{array}$ & $\begin{array}{c}13.3 \pm 0.6 \\
b\end{array}$ & $\begin{array}{c}\mathrm{F}_{2,6}=12.8 \\
\mathrm{P}<0.01\end{array}$ & $\begin{array}{c}5.0 \pm 0.4 \\
\mathrm{a}\end{array}$ & $\begin{array}{c}2.2 \pm 0.2 \\
\mathrm{c}\end{array}$ & $\begin{array}{c}3.4 \pm 0.1 \\
\mathrm{~b}\end{array}$ & $\begin{aligned} \mathrm{F}_{2,6} & =23.94 \\
\mathrm{P} & <0.01\end{aligned}$ \\
\hline
\end{tabular}

One-way analysis of variance (ANOVA) and DUNCAN tests were applied to the data and the differences between the means were calculated at the significance level of $\mathrm{P}<0.05$.

\subsection{Proline and total amino acid concentrations}

In all three fruits, proline concentration of V.a. ssp. album was observed to be higher than control and host (Table 4).

Table 4. Proline concentration (mg/g) of control, hosts and V. a. ssp. album

\begin{tabular}{lllll}
\hline \multirow{2}{*}{ Fruit trees } & \multicolumn{4}{l}{ Proline concentration $(\mathbf{m g} / \mathbf{g})$} \\
\cline { 2 - 5 } Breaburn apple & Control & Host & V. a. ssp. album & F and P \\
& $0.02 \pm 0.05$ & $0.04 \pm 0.001$ & $0.11 \pm 0.001$ & $\mathrm{~F}_{2,6}=7.69$ \\
Ankara pear & $\mathrm{b}$ & $\mathrm{b}$ & $\mathrm{a}$ & $\mathrm{P}<0.05$ \\
& $0.03 \pm 0.002$ & $0.05 \pm 0.002$ & $0.41 \pm 0.02$ & $\mathrm{~F}_{2,6}=134.61$ \\
Hawthorn & $\mathrm{b}$ & $\mathrm{b}$ & $\mathrm{a}$ & $\mathrm{P}<0.0001$ \\
& $0.04 \pm 0.01$ & $0.01 \pm 0.002$ & $0.25 \pm 0.02$ & $\mathrm{~F}_{2,6}=62.58$ \\
& $\mathrm{~b}$ & $\mathrm{~b}$ & $\mathrm{a}$ & $\mathrm{P}<0.0001$ \\
\hline
\end{tabular}

One-way analysis of variance (ANOVA) and DUNCAN tests were applied to the data and the differences between the means were calculated at the significance level of $\mathrm{P}<0.05$.

Total amino acid concentration of $V$. a. ssp. album was calculated to be less than control in three fruits, while it was lower than host for Breaburn apple, higher than host for Ankara pear and similar to the host for hawthorn (Table 5).

Table 5. Amino acid concentrations (mg/g) of control, hosts and V.a. ssp. album

\begin{tabular}{lllll}
\hline \multirow{2}{*}{ Fruit trees } & \multicolumn{4}{l}{ Total amino acid content $(\mathbf{m g} / \mathbf{g})$} \\
\cline { 2 - 5 } Breaburn apple & Control & Host & V. a. ssp. album & F and P \\
& $4.30 \pm 0.17$ & $2.92 \pm 0.001$ & $2.14 \pm 0.204$ & $\mathrm{~F}_{2,6}=37.17$ \\
Ankara pear & $\mathrm{a}$ & $\mathrm{b}$ & $\mathrm{c}$ & $\mathrm{P}<0.001$ \\
& $3.95 \pm 0.37$ & $0.430 \pm 0.051$ & $2.630 \pm 0.219$ & $\mathrm{~F}_{2,6}=$ Infinity \\
Hawthorn & $\mathrm{a}$ & $\mathrm{c}$ & $\mathrm{b}$ & $\mathrm{P}<0.0001$ \\
& $4.45 \pm 0.01$ & $1.550 \pm 0.106$ & $1.59 \pm 0.206$ & $\mathrm{~F}_{2,6}=91.31$ \\
\hline
\end{tabular}

One-way analysis of variance (ANOVA) and DUNCAN tests were applied to the data and the differences between the means were calculated at the significance level of $\mathrm{P}<0.05$. 


\subsection{Ascorbic acid concentration ( $\mathrm{mg} / \mathrm{g})$}

Reduced ascorbic acid concentration of $V$. $a$. ssp. album in three fruits was determined to be significantly lower than control (Table 6). Reduced ascorbic acid of $V$. a. ssp. album was found similar to the host in Breaburn and hawtron whereas it was determined to be less than the host for Ankara pear.

Table 6. Ascorbic acid concentrations (mg/g) of control, hosts and V.a. ssp. album

\begin{tabular}{|c|c|c|c|c|c|c|c|c|}
\hline \multirow[b]{2}{*}{ Fruit trees } & \multicolumn{4}{|c|}{ Reduced ascorbic acid (mg/mL) } & \multicolumn{4}{|c|}{ Total ascorbic acid $(\mathrm{mg} / \mathrm{mL})$} \\
\hline & Control & Host & $\begin{array}{lll}V . \quad a . & \text { ssp. } \\
\text { album } & \end{array}$ & $F$ and $P$ & Control & Host & 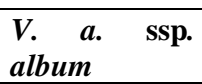 & $F$ and $P$ \\
\hline $\begin{array}{l}\text { Breaburn } \\
\text { apple }\end{array}$ & $\begin{array}{l}0.155 \pm 0.003 \\
\mathrm{a}\end{array}$ & $\begin{array}{l}0.147 \pm 0.0 \\
02 \\
\text { b }\end{array}$ & $\begin{array}{l}0.142 \pm 0 \\
\mathrm{~b}\end{array}$ & $\begin{array}{l}\mathrm{F}_{2,6}=7.94 \\
\mathrm{P}<0.05\end{array}$ & $\begin{array}{l}0.148 \pm 0 \\
\mathrm{a}\end{array}$ & $\begin{array}{l}0.144 \pm 0.001 \\
\mathrm{~b}\end{array}$ & $\begin{array}{l}0.142 \pm 0.004 \\
\text { c }\end{array}$ & $\begin{array}{l}\mathrm{F}_{2,6}=\text { Infinity } \\
\mathrm{P}<0.0001\end{array}$ \\
\hline Ankara pear & $\begin{array}{l}0.152 \pm 0.006 \\
\mathrm{a}\end{array}$ & $\begin{array}{l}0.143 \pm 0 \\
\mathrm{~b}\end{array}$ & $\begin{array}{l}0.135 \pm 0 \\
\mathrm{c}\end{array}$ & $\begin{array}{l}\mathrm{F}_{2,6}=28.28 \\
\mathrm{P}<0.001\end{array}$ & $\begin{array}{l}0.150 \pm 0.003 \\
\mathrm{a}\end{array}$ & $\begin{array}{l}0.144 \pm 0.001 \\
\mathrm{~b}\end{array}$ & $\begin{array}{l}0.137 \pm 0 \\
\mathrm{c}\end{array}$ & $\begin{array}{l}\mathrm{F}_{2,6}=97.00 \\
\mathrm{P}<0.0001\end{array}$ \\
\hline Hawthorn & $\begin{array}{l}0.144 \pm 0.002 \\
\mathrm{a}\end{array}$ & $\begin{array}{l}0.135 \pm 0.0 \\
02 \\
\text { b }\end{array}$ & $\begin{array}{l}0.134 \pm 0.001 \\
\mathrm{~b}\end{array}$ & $\begin{array}{l}\mathrm{F}_{2,6}=20.73 \\
\mathrm{P}<0.01\end{array}$ & $\begin{array}{l}0.145 \pm 0.003 \\
\mathrm{a}\end{array}$ & $\begin{array}{l}0.136 \pm 0 \\
\mathrm{~b}\end{array}$ & $\begin{array}{l}0.134 \pm 0 \\
\mathrm{~b}\end{array}$ & $\begin{array}{l}\mathrm{F}_{2,6}=18.05 \\
\mathrm{P}<0.01\end{array}$ \\
\hline
\end{tabular}

One-way analysis of variance (ANOVA) and DUNCAN tests were applied to the data and the differences between the means were calculated at the significance level of $\mathrm{P}<0.05$.

Total ascorbic acid concentration of $V$. a. ssp. album was less than control and host for Breaburn and Ankara pear. However, the value was alike in the host for hawthorn.

\subsection{Glucose and fructose concentrations}

Glucose concentration of $V$. a. ssp. album was lower than control and host in three fruit species (Table 7). However, the fructose concentration of $V$. $a$. ssp. album was less than control and host for Breaburn apple and Ankara pear. Fructose concentration of $V$. a. ssp. album, however, was found to be similar with control for hawthorn.

Table 7. Glucose and fructose concentrations (mg/g) of control, hosts and V.a. ssp. album

\begin{tabular}{|c|c|c|c|c|c|c|c|c|}
\hline \multirow[b]{2}{*}{ Fruit trees } & \multicolumn{4}{|c|}{ Glucose content (mg/g) } & \multicolumn{4}{|c|}{ Fructose content (mg/g) } \\
\hline & Control & Host & $\begin{array}{ll}\begin{array}{l}\text { V.a. } \\
\text { album }\end{array} & \text { ssp. } \\
\end{array}$ & $F$ and $P$ & Control & Host & $\begin{array}{ll}\begin{array}{l}\text { V.a. } \\
\text { album }\end{array} & \text { ssp. } \\
\end{array}$ & $F$ and $P$ \\
\hline $\begin{array}{l}\text { Breaburn } \\
\text { apple }\end{array}$ & $\begin{array}{l}0.567 \pm 0.02 \\
\mathrm{a}\end{array}$ & $\begin{array}{l}0.469 \pm 0.131 \\
b\end{array}$ & $\begin{array}{l}0.117 \pm 0.011 \\
\text { c }\end{array}$ & $\begin{array}{l}\mathrm{F}_{2,6}=2191.6 \\
\mathrm{P}<0.0001\end{array}$ & $\begin{array}{l}0.688 \pm 0.007 \\
\mathrm{a}\end{array}$ & $\begin{array}{l}0.568 \pm 0.024 \\
\text { b }\end{array}$ & $\begin{array}{l}0.201 \pm 0.03 \\
\text { c }\end{array}$ & $\begin{array}{l}F_{2,6}=108.50 \\
P<0.0001\end{array}$ \\
\hline Ankara pear & $\begin{array}{l}0.445 \pm 0.08 \\
\mathrm{a}\end{array}$ & $\begin{array}{l}0.261 \pm 0.076 \\
\mathrm{~b}\end{array}$ & $\begin{array}{l}0.059 \pm 0.014 \\
\text { c }\end{array}$ & $\begin{array}{l}\mathrm{F}_{2,6}=11.93 \\
\mathrm{P}<0.01\end{array}$ & $\begin{array}{l}0.406 \pm 0.002 \\
\mathrm{a}\end{array}$ & $\begin{array}{l}0.317 \pm 0.017 \\
\text { b }\end{array}$ & $\begin{array}{l}0.125 \pm 0.01 \\
\mathrm{c}\end{array}$ & $\begin{array}{l}\mathrm{F}_{2,6}=103.9 \\
\mathrm{P}<0.0001\end{array}$ \\
\hline Hawthorn & $\begin{array}{l}0.225 \pm 0.01 \\
\mathrm{a}\end{array}$ & $\begin{array}{l}0.173 \pm 0.092 \\
\mathrm{~b}\end{array}$ & $\begin{array}{l}0.098 \pm 0.002 \\
\text { c }\end{array}$ & $\begin{array}{l}\mathrm{F}_{2,6}=173.62 \\
\mathrm{P}<0.0001\end{array}$ & $\begin{array}{l}0.313 \pm 0.005 \\
\mathrm{a}\end{array}$ & $\begin{array}{l}0.258 \pm 0.081 \\
\mathrm{~b}\end{array}$ & $\begin{array}{l}0.075 \pm 0.01 \\
\mathrm{~b}\end{array}$ & $\begin{array}{l}F_{2,6}=6.76 \\
P<0.05\end{array}$ \\
\hline
\end{tabular}

One-way analysis of variance (ANOVA) and DUNCAN tests were applied to the data and the differences between the means were calculated at the significance level of $\mathrm{P}<0.05$.

\subsection{Sulfhydryl concentrations}

Sulfhydryl (SH) concentration of $V$. a. ssp. album was found to be lower than control and host in three fruits (Table 8). 
Table 8. SH concentration (ppm) of control, hosts and V. a. ssp. album

\begin{tabular}{lllll}
\hline \multirow{2}{*}{ Fruit trees } & \multicolumn{2}{l}{ SH concentration ( ppm) } \\
\cline { 2 - 5 } Breaburn apple & Control & Host & V. a. ssp. album & F and P \\
& $0.142 \pm 0.0001$ & $0.139 \pm 0.0004$ & $0.136 \pm 0.0001$ & $\mathrm{~F}_{2,6}=43.00$ \\
Ankara pear & $\mathrm{a}$ & $\mathrm{b}$ & $\mathrm{c}$ & $\mathrm{P}<0.001$ \\
& $0.101 \pm 0.0001$ & $0.099 \pm 0.0001$ & $0.097 \pm 0$ & $\mathrm{~F}_{2,6}=37.00$ \\
Hawthorn & $\mathrm{a}$ & $\mathrm{b}$ & $\mathrm{c}$ & $\mathrm{P}<0.001$ \\
& $0.102 \pm 0$ & $0.098 \pm 0.0001$ & $0.097 \pm 0$ & $\mathrm{~F}_{2,6}=$ Infity \\
\hline
\end{tabular}

One-way analysis of variance (ANOVA) and DUNCAN tests were applied to the data and the differences between the means were calculated at the significance level of $\mathrm{P}<0.05$.

According to the results of statistical analysis, leaf proportional water content of $V$. $a$. ssp. album were 3-4 times higher than control and host in three fruits. In addition, leaf proportional water contents of control and host were found to be similar to each other. Leaf water status is intimately related to several leaf physiological variables, such as leaf turgor, growth, stomatal conductance, transpiration, photosynthesis and respiration [26]. Hawksworth and Wiens [6] showed that Dwarf mistletoe has conductance in the parasite was typically from 2 to 5 times that of the host. Mistletoes most successfully compete for a share of the host's water. It has been previously found that mistletoe on trees has a more than 3 fold higher transpiration rate, calculated by leaf surface, compared to the host. Compared with the control, the leaf relative water content of mistletoe was found much higher than its host [18,19,27-29].

According to our findings, $V$. a. ssp. album seemed to have a lower chlorophyll a content than control and hosts for Breaburn apple and Ankara pear. Chlorophyll a content of $V$. a. ssp. album was resembling the one measured for the hosts in hawthorn. Chlorophyll b content of $V$. a. ssp. album, however, was found to be lower than control and similar to the host for Breaburn apple. On the other hand, it was similar to the control and host for Ankara pear and hawthorn. The negative effects of compulsory hemiparasitic weeds on photosynthesis were also observed on the hosts. Viscum album is able to produce its own assimilates in the process of photosynthesis. V. album has a high transpiration rate, similar to many other parasitic plants and a low photosynthetic rate. In previous studies, the value of chlorophyll a in the mistletoe has been shown to be significantly lower than hosts. The invasion of parasite in the mango (host) has also been reported to alter the ratio between chlorophyll a and $b$, probably affecting the photosynthetic efficiency $[9,12,30,31]$. In our study, chlorophyll a content of mistletoe was found to be higher than chlorophyll $b$ wihile Oyetunji and Edagbo [18] showed that both host (Citrus, Irvingia) and African mistletoe (Tapinanthus bangwensis) have higher chlorophyll b contents.

The total chlorophyll and carotenoid contents of $V$. a. ssp. album were less than control and host for Breaburn and Ankara pear. However the total chlorophyll was measured to be similar to the host for hawthorn and $V$. a. ssp. album. This probably resulted from the low level photosynthesis activity. Total chlorophyll of $V$. album in hawthorn was similar to its host while carotenoid content was higher than host. $V$. album contains all of the pigments, chlorophyll a and $\mathrm{b}$ as well as carotenoid that are necessary for photosynthesis [32]. In a report published by Oyetunji and Edagbo, total chlorophyll content of the mistletoe and hosts exhibited values in which the total chlorophyll of the Citrus was significantly higher while the total chlorophyll content for the mistletoe-Irvingia relationship was not statistically different [18]. Semi parasite plant has total chlorophyll and carotenoids more much than control plants [19].

Proline content of $V$. a. ssp. album was higher than control and host in three fruits. This is probably due to the stress arising from abiotic factors for $V$. $a$. ssp. album. The increase of proline concentration promotes proline oxidation while it inhibits protein synthesis [33]. It was reported that proline is a nitrogen compound that increased in stress condition, participated in detoxification of free $\mathrm{O}_{2}$ and contained protective properties in the stress conditions [34]. Many authors stated that the contents of proline and relative chlorophyll increased with the effect of oxidative stress [20, 35, 36]. Mistletoe-host associations have shown that the potassium and proline contents of mistletoes were the 
highest among other major nutrients and osmotically active solutes, thus playing a vital role in osmotica of the parasite [37, 38]. In another study, it has been demonstrated that the concentration of proline in the leaf of Washington and Valencia increased after pesticide application [39]. Erwinia amylovora is a biological stress factor causing increase in the content of proline and ascorbic peroxidase in apples and pears [40]. The results of the present study are in accordance with Murugan et al. [19] who showed that semi parasite plant has much more proline than control plants.

Total amino acid concentrations of $V$. a. ssp. album were found to be less than control in three fruits, while it was less than host for Breaburn apple, higher than host for Ankara pear. It was also found to be similar to the host for hawthorn. Since misletoe takes the required nutrients from its host, amino acid content of fruit tree is reduced. A significantly lower content of leaf protein in most species of the infected trees was observed when compared to the uninfected trees [41]. Dendrophthoe falcate, which is also a semiparasitic plant, increased amino acid content in its host. While the total protein, phenols, flavonoids also showed a defense related response in the plant, the chlorophyll content showed a decrease in the infected plant [19]. In autumn, V. album collected from Crataegus had the lowest protein content whereas protein content in the leaves of mistletoe hosted by Acer, Populous, and Robinia did not change significantly in different seasons [42].

Total and reduced ascorbic acid content of $V$. a. ssp. album in three fruits were found to be lower than the uninfected plants. Their content in hosts were lower than control. This is most likely due to the taking of ascorbic acid by $V$. a. ssp. album from their host. It has been reported that some hosts of Viscum album subspecies, such as apples, cherries, pears and plums, contain ascorbic acid [43], and that ascorbic acid content decreases in stress conditions (salt and metal) in some plant species while some increase it as an antioxidant defense mechanism [44, 45].

Glucose and fructose contents of $V$. $a$. ssp. album in three fruits were found to be lower than control and host. This observation may be explained by the fact that glucose and fructose can be intaken by $V$. a. ssp. album from its host. Glucose, galactose, fructose, saccarose, galacturonic acid, and pectine were found in the leaf of mistletoe [46, 47]. The quantity of the fructose and glucose in the mistletoe that was parasitic on Irvingia were higher than that on Citrus. However, the host plants had more of these reducing sugars than the semiparasite. This further suggests that the semi parasite depends on the host for little sugar supply from its host to complement its weak photosynthetic activities [18]. In a study conducted by Murugan et al., reduction in soluble sugar contents were noted in the infected mango plant by the parasite Dendrophthoe falcata. Under parasitic stress conditions, total soluble sugar content decreased considerably. Parallely in the control, the total soluble sugar content was remarkably higher. A significant decrease in total soluble sugar content under biotic stress was observed in the infected host [19].

The content of SH in three fruits was highest in the leaf of control and they were at a lower level in their hosts while they were the lowest in the leaf of $V$. $a$. ssp. album. The fact that SH content of hosts were lower than controls was probably resulted from the mistleteo stress factor. SH content in the plant tissues increases in spring compared to winter months. SH content of the plants may be elevated by the cold and water stress in the photosynthesis reaction. Reactive oxygen species and free radicals oxidate nucleic acids, proteins and lipids in the oxidative stress period. It has also been determined by researchers that antioxidants may be reduced in the event of stress in different environments [48-50]. SH contents in the leaf of Washington and Valencia were found to be at higher levels before pesticid application [39]. V. album may have detrimental effect on leaf structure, physiology and chemical composition of highly infected host trees [51]. It is widely appreciated that the chemical composition of mistletoe is not stable and it depends not only on biosynthesis but also on the type of host plant and growth conditions, such as ambient temperature, carbon dioxide concentration and season of the year $[52,53]$.

\section{Conclusion}

Due to the fact mistletoe uses the water and nutrients of the host, the proportional water content, chlorophyll a-b, caratoneid, proline, total amino acid, ascorbic acid, glucose, fructose and SH contents of $V$. a. ssp. album showed a variation. At the same time, these parameters appear to be 
affected by the morphological and biological characteristics of hosts as well as the soil properties and ecological properties of the region.

\section{Acknoledgement}

This project was supported by Kahramanmaras Sutcu Imam University, Scientific Research Projects Unit with the project number of 2013/1-22M.

\section{ORCID}

Tamer Üstüner: 0000-0003-3584-4249

Sema Düzenli: $\underline{0000-0002-2506-6415}$

\section{References}

[1] A.G. Miller (1982). Arceuthobium Bieb. and Viscum album L. (Flora of Turkey and the East Aegean Islands), University press, Edinburgh.

[2] M. Calder and P. Bernhardt (1983). The Biology of mistletoes. Sydney, New York, London, Paris, San Diego, San Francisco, Sao Paolo, Tokyo, Toronto: Academic press.

[3] D.B. Fischer (1983). Year round collection of willow sieve tube exudate, Planta 159, 529-533.

[4] J.R. Ehleringer, E.D. Schultze, H. Ziegler, O.L. Lange, G.D. Farquhar and I.R. Cowar (1985). Xylemtapping mistletoes: Water or nutrient parasites, Science 227, 1479-1481.

[5] F.G. Hawksworth and R.F. Scharpf (1986). Spread of European mistletoe (Viscum album L.) in California,U.S.A, Eur. J. Forest Pathol. 6,1-5.

[6] F.G. Hawksworth and D. Wiens (1996). Dwarf mistletoes (Viscum album L.), Biology, pathology and systematics. U.S.A. Department of Agriculture forest service, Agricultural Handbook 709.

[7] D.M. Watson (2001). Mistletoe A keystone resource in forests and woodlands worldwide, Annual Rev. Ecol. Syst. 32, 219-249.

[8] J. Briggs (2003). Christmas curiosity or medical marvel? A seasonal review of mistletoe, Biologist 50, 249-254.

[9] D. Zuber (2004). Biological flora of central Europe: Viscum album L., Flora 199, 188-203.

[10] D. Zuber and A. Widmer (2009). Phylogeography and host race differentiation in the European mistletoe (Viscum album L.), Mol. Ecol. 18, 1946-1962002E|01.

[11] C. Türe, H. Böcük and A. Zerrin (2010). Nutritional relation-ships between hemi-parasitic mistletoe and some of its deciduous hosts in different habitats. Vicas, S., Biol. Section Bot. 65, 859-867.

[12] H.S. Heide-Jorgensen (2004). About Viscum a mistletoe Viscum dk.http://www.Viscum.dk/engsider/about Viscum.htm).

[13] N. Zeybek (1985). Pharmaceutical botany, closed seeded plants system (Angiospermae) and important components, Ege University, Pharmacy Faculty. Ege University printing house, İzmir-Turkey, Number, 1.

[14] T. Üstüner (2003). Identification and density of Viscum species in Nigde province, The J. Turk. Weed Sci. $6(2), 45-53$.

[15] T. Üstüner, S. Düzenli and Y.E. Kitis (2015). Determination of infection rate of mistletoe (Viscum album) on hosts in Nigde province, The J. Turk. Weed Sci. 18(1), 6-14.

[16] P. Escher, M. Eiblmeier, I. Hetzger and H. Rennenberg (2004). Seasonal and spatial variation of carbohydrates in mistletoes (Viscum album) and the xylem sap of its hosts (Populus euamericana and Abies alba), Physiol. Plantar. 120, 212-219.

[17] H. Ziegler, J. Weber and U. E. Lüttge (2009). Thermal dissipation probe measurements of sap flow in the xylem of trees documenting dynamic relations to variable transpiration given by instantaneous weather changes and the activities of a mistletoe xylem parasite, Trees. 23, 441-450.

[18] O.J. Oyetunji and D.E. Edagbo (2013). Comparative ecophysiological study of Tapinanthus bangwensis, [Engl. And R. Krause] Danser (African Mistletoe) On two host plants, J. of Chem. Bio. Phy. Sci. 3, 1933-1941.

[19] R. Krishnan, A.S. Lubaina and K. Murugan (2014). Interaction between hemiparasitic (Dendrophthoe falcata (L.) Ettıng.) on mangifera Indica lınn. Some observatıons. World J. Pharm. Pharmaceut. Sci. 3(6), 585-607. 
[20] R.K. Sairam, K.V. Rao and G.C. Srivastava (2002). Differential response of wheat genotypes to long term salinity stress in relation to oxidative stress, antioxidant activity and osmolyte concentration, Plant Sci. 163, 1037-1046.

[21] D.M. Arnon (1949). Copper enzymes in isolated chloroplasts poly phanoloxidase in Beta vulgaris, Plant Physiol. 24, 1-15.

[22] H.K. Lichtenthaler and A.R. Wellburn (1983). Determinations of total carotenoids and chlorophyll a and b of leaf extracts in different solvents, Biochem. Soc. Transac. 11, 591-592.

[23] I. Cakmak and H. Marschner ( 1992). Magnesium deficiency and high light intensity enhance activities of superoxide dismutase, ascorbate peroxidase and glutatione reductase in bean leaves, Plant Phsiol. 98,1222-1227.

[24] J.R. Spies (1957). Colorimetric procedures for amino acids. In: Methods in enzymology. III. (Ed. by S. P. Colowick and N. O. Kaplan), Academic press, New York, 468-471.

[25] L.S. Bates, R.P. Waldren and I.D. Teare (1973). Rapid determination of free proline for water-stress Studies, Plant Soil 39, 205-207.

[26] P.J. Kramer and J.S. Boyer (1995). Water relation of plants and soils. Academic press, San Diego, 495.

[27] E.D. Schulze, N.C. Turner and G. Glatzel (1984). Carbon, water and nutrient relationships of two mistletoes and their hosts: A hypothesis, Plant Cell environ. 7, 293-299.

[28] S.M. Hosseini, D. Kartoolinejad, S.K. Mirnia, Z. Tabibzadeh, M. Akbarinia and F. Shayanmehr (2008). The European mistletoe effects on leaves and nutritional elements of two host species in Hyrcanian forests. Silva Lusitana, C EFN, Lisboa, Portugal 16 (2), 229-237.

[29] G. Glatzel and B.W. Geils (2009). Mistletoe ecophysiology: Host-parasite interactions. Botany. 87, 10.

[30] K.U. Tennakoon and J.S. Pate (1996). Effect of parasitism by a mistletoe on the structure and functioning of branches of its host-plant. Cell and environment. 19, 517-528.

[31] A. Chatterjee and S.K. Ghosh (2008). Alterations in biochemical components in mesta plants infected with yellow vein mosaic disease, Braz J. Plant Physiol. 20 (4), 267-275.

[32] H. Becker (2000). European mistletoe: Taxonomy, host trees, parts used, physiology. In: Mistletoe: The genus Viscum, ed. A. Büssing, Harwood Academic publishers.

[33] N. Smirnoff and S.V. .Colombe (1988). Drought influecens the activity of the chloroplast hydrogen peroxide scavenging system, J. Experiment. Bot. 39, 1097-1108.

[34] H.J. Bohnert and E. Sheveleva (1998). Plant stress adaptations making metabolism move, Curr. Opinion in Plant Biol. 1, 267-277.

[35] R.K. Sairam, D.S. Shukla and D.C. Saxena (1998). Stress induced injury and antioxidant enzymes in relation to drought tolerance in wheat genotypes, Biol. Plantar. 40, 357-364.

[36] R.K. Sairam and D.C. Saxena (2000). Oxidative stress and antioxidants in wheat genotypes: Possible mechanism of water stress tolerance, J. Agronomy Crop Sci. 184 (1), 55-61. DOI:10.1046/j.1439037x.2000.00358.xView/save citation.

[37] L.C. McDowell (1964). Physiological relationships between dwarf mistletoe and ponderosa pine, Oregon state university, Corvallis, OR, Oregon State University, 68.

[38] J.M. Hibberd and W.D. Jeschke (2001). Solute flux into parasitic plants, J. Exp. Botany. 52 (363), 2043-2049.

[39] A. Fidan and S. Düzenli (2007). The effects of some pesticides on the physiological and anatomical properties of citrus varieties. Cukurova univerisity, Institute of natural and applied sciences, MSc thesis, Page: 40. Adana-Turkey.

[40] E. Karacif and N. Boyraz (2012). Determination of levels of some antioxidat and enzymes after infection with Erwinia amylovora of apple and pear varieties. Selcuk university, The graduate school of natural and applied science, The degree of master of science, Plant protection, June, Konya-Turkey.

[41] J. Patykowski and J. Kołodziejek (2013). Comparative analysis of antioxidant activity in leaves of different hosts infected by mistletoe (V. album L. subsp. album), Archives Biol. Sci. 65, 851.

[42] J. Patykowski and J. Kołodziejek (2016). Changes in antioxidant enzyme activities of European mistletoe ( $V$. album subsp. album) leaves as a response to environmental stress caused by pollution of the atmosphere by nitrogen dioxide, Pol. J. Environ. Stud. 25 (2), 725-732.

[43] W.C. Evans (1989). Trease and Evans' pharmacognosy, Bailliere Tindall, London, 13. Edition, 665.

[44] R.K. Sairam, G.C. Srivastava, S. Agarwal and R.C. Meena (2005). Differences in antioxidant activity in response to salinity stress in tolerant and susceptible wheat genotypes, Biol. Plantar. 49, 85-91.

[45] M. Tiryakioglu, S. Eker, F. Ozkutlu, S. Husted and I. Cakmak (2006). Antioxidant defense system and cadmium uptake in barley genotypes differing in cadmium tolerance, J. Trace Elem. Med. Biol. 20,181189.

[46] O.I. Popova and D.A. Murav'eva (1990). Polysaccharides of mistletoe (Viscum album) polysaccharide fractions from European mistletoe and firmiana, Farmatsiya 39 (5), 41-44. 
[47] O.I. Popova (1991). Phenolic acids of Viscum album, Khim, Prir. Soedin. 1, 139-140.

[48] I.K. Smith, A.C. Kendall, A.J. Keys, J.C. Turner and P.J. Lea (1985). The regulation of the biosynthesis of glutathione in leaves of barley (Hordeum vulgare L.), Plant Sci. 41,11-17.

[49] D.M. Hodges and C.F. Forney (2000). The effects on ethylene, depressed oxygene and elevated carbon dioxide on antioxidant profiles of senescing spinach leaves, J. Experiment. Bot. 51 (334), 645- 655.

[50] I. Meram and S. Aktaran (2002). Effects of free radicals on biomolecules, Archive 11, 299.

[51] M.G. Daryaei and E.S. Moghadam (2012). Effects of mistletoe (Viscum album) on leaves and nutrients content of some host trees in Hyrcanian forests (Iran). International Journal of Agriculture: Res. Review 2 (3), 85-90.

[52] P. Stypiński (1997). Biology and ecology of mistletoe (Viscum album, Viscaceae) in Poland, Instytut Botaniki im. W. Szafera PAN, Kraków, 1-117.

[53] M. Łuczkiewicz, W. Cisowski, P. Kaiser, R. Ochocki and A. Piotrowski (2001). Comparative analysis of phenolic acids in mistletoe plants from various hosts, Acta Pol. Pharm. 58, 373-379.

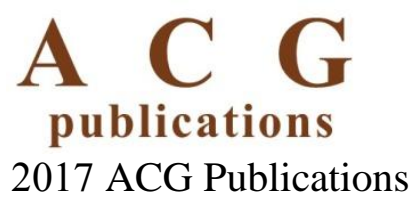

